\title{
Comparative Physicochemical Analysis of Kushta-E-Murdarsang Prepared by Classical and Muffle Furness Method
}

\author{
Mohd Akhtar Ali ${ }^{1}$, Hamiduddin², Mohammad Zaigham², Sana Nafees ${ }^{2}$, Mohammad Ikram², Gazi Jahangeer ${ }^{2}$ \\ 'Department of Ilmul Saidla (Unani Pharmacy), Z.H. Unani Medical Collage and Hospital, Siwan, Bihar, INIDA. \\ ${ }^{2}$ Department of IImul Saidla (Unani Pharmacy), National Institute of Unani Medicine (NIUM), Kottigepalya, Magadi Main road, Bengaluru, Karnataka, INDIA.
}

\begin{abstract}
Aim: Kushta-e-Murdarsang a herbo-mineral calx preparation was prepared as per classical and contemporary method and its physico-chemical and elemental analysis for standardization and safety evaluation (by heavy metal estimation) was performed. Methods: Murdarsang (Litharge mineral) was subjected to Mudabbar / Shodhan (processing) by Sheere-Madar (Latex of Calotropis gigantea Linn. R. Br. ex. Ait.) and calcined by classical and muffle furness method. Comparative Physico-chemical investigation for safety evaluation and standardization were done by $X$-ray diffraction (XRD), inductively coupled plasma mass spectrometry (ICP-MS), Atomic absorption spectroscopy (AAS) and other analytical parameters. Results: Both the sample Kushta-e-Murdarsang classical method (KM-CM) and Kushta-e-Murdarsang Muffle Furnace method (KM-MFM) passed specification tests as per Unani Medicine. Both the sample KM-CM and KM-MFM showed presence of heavy metals. In XRD analysis both the samples showed presence of Lead, sample KM-MFM revealed presence of Litharge syn- $\mathrm{PbO}$ phase, where KM-CM revealed presence of Lead syn- $\mathrm{Pb}$, Galena syn- $\mathrm{Pb} \mathrm{S}$ and Litharge syn- $\mathrm{PbO}$ phase. In ICP-MS analysis the Cadmium $(\mathrm{Cd})$ content was $0.65 \mathrm{ppm}$ and $0.65 \mathrm{ppm}$; Mercury $(\mathrm{Hg})$
\end{abstract}

$54.17 \mathrm{ppm}$ and $68.08 \mathrm{ppm}$ and Arsenic (As) was $21.27 \mathrm{ppm}$ and $0.11 \mathrm{ppm}$ accordingly, in AAS analysis the Lead (Pb) content was $55.0 \%$ and $51.4 \%$ in KM-MFM and KM-CM respectively. Conclusion: KM-MFM can be a better choice in respect of only ease of preparation, both the sample prepared by classical along with muffle furnace method contains heavy metal above permissible limit and KM-CM contain reduced quantity of heavy metal in respect of MF method. XRD and other standardization data for the formulation were set in.

Key words: Murdarsang, Lead monoxide, Litharge, Unani Medicine, Kushta, Safety.

Correspondence

Assistant Prof. Hamiduddin,

Department of Ilmul Saidla (Unani Pharmacy), National Institute of Unani Medicine (NIUM) Kottigepalya, Magadi main Road, Bengaluru-560091, Karnataka, INDIA.

Email id: drhamid2003@rediffmail.com

DOI: 10.5530/jyp.2021.13.43

\section{INTRODUCTION}

Mineral and metals in calcined (Kushta) form are used in traditional medicine since antiquity. It is also termed as a very potent dosage form in Unani System of Medicine (USM) also and is indicated in various diseases. ${ }^{1}$ In Persian Kushtan means "To Kill". Kushta's are made for various purposes in order to make the drug simple for utilize, to reduce the dose and enhance the effectiveness of the drug, and to eliminate the harmful and detrimental materials / effect from it. ${ }^{1,2}$ The adverse effects of some mineral origin drugs have given awareness among researchers to use these drugs in the form of Kushta as well as to assess the margin of safety between the dose level that produces the healing property and that produces the adverse effects, that is to provide benefit to risk assessment. ${ }^{3}$ There is a need to evaluate the type of mineral, metal content and their form in Kushta. It can be accomplished by various analytical procedures. In this work, the Kushta of one such metal ore i.e. Murdarsang was evaluated. Murdarsang is a mineral origin drug, it can be prepared synthetically, Murdarsang is Lead monoxide or litharge. ${ }^{4}$ In Unani Medicine its Jila (cleansing) activity cleans the wound, engulf the dead tissues and help in developing granulation tissues. It acts as Muhallil (resolvent), Mujaffif (desiccant) and Qabiz (astringent). It is used in Buthur Labaniyya (acne vulgaris) and Tar wa Khushk Khujli (Scabies and Pruritus). It is generally used in skin diseases formulations that are usually applied externally / topically. ${ }^{5}$ Murdarsang is basically termed as mono-oxide of lead. ${ }^{6}$

Kushta-e-Murdarsang is one of the Kushta used in Unani Medicine generally topically. It is also commonly used as Muqawwi-i-Bah (aphrodisiac) and Musaffi-i-Dam (blood purifier) and in Asthma, Cough, Syphilis,
Gonorrhea, haemorrhage and Snake bite. ${ }^{1}$ In this work Comparative Physicochemical analysis of Kushta-e-Murdarsang prepared by Classical and Muffle Furnace method was performed to set the standardization parameters and for comment on its safety in respect of presence of heavy metal and its form.

\section{MATERIALS AND METHODS}

This study was carried out in the Department of Ilmul Saidla, National Institute of Unani Medicine (NIUM), Indian Institute of sciences (IISc) Bengaluru and other accredited laboratories. Murdarsang was obtained from apothecary shop in Bengaluru; Sheer-e-Madar (latex of Calotropis gigantea (Linn.) R.Br.ex.Ait.) was obtained from herbal garden of National Institute of Unani medicine, Bangalore. Murdarsang was identified by expert at NIUM, Bengaluru and was further confirmed by X-ray diffraction (XRD).

\section{Method of Mudabbar Detoxification/ Processing of Murdarsang}

The Mudabbar (detoxification) process of Murdarsang was done by powdering $100 \mathrm{gm}$ of Murdarsang with Sheer-e-Madar (Milk-weed, Calotropis gigantea (Linn.) R. Br. ex. Ait.) with the help of Mortar and Pestle manually and filtered through muslin cloth ; two Tola (24 gm) of Murdarsang and fresh Sheer-e-Madar as per need (about five ml) was

This is an open access article distributed under the terms of the Creative Commons Attribution-NonCommercial-ShareAlike 4.0 License, which allows others to remix, tweak, and build upon the work non-commercially, as long as the author is credited and the new creations are licensed under the identical terms. 
taken in a Buta and mixed then left for eight Pahar (48 hrs) as per method mentioned in the text. ${ }^{1}$ Figure 1

\section{Preparation of Kushta-e-Murdarsang}

Triturated Murdarsang and mixed and dried in Sheer-e-Madar (latex) was taken in clay crucible (Buta) and covered with clay lid and sealed by the method of Gille Hikmat and kept for drying in a shade. ${ }^{1}$

\section{Preparation of Kushta by classical Method}

In this method the pit was dug which can accommodate $2 \mathrm{~kg}$ cow dung cakes. The Buta (clay crucible) after drying in the shade was placed in a pit and set fire with $2 \mathrm{~kg}$ Uple (cow-dung cakes) at the place protected from wind, after cooling Kushta was collected for further analysis. ${ }^{1}$

Changes in drugs subjected to calcination and quenching media were intensely observed and heat pattern was recorded at 15 minutes time intervals during the calcination process by the help of thermocouple, sensor of which is located near Buta in the pit. Maximum temperature of $483^{\circ} \mathrm{C}$ was recorded at the peak and detail thermogram was obtained (Figure 2)

\section{Preparation of Kushta by Muffle Furnace (MF) method}

The Buta after drying in the shade was placed in Muffle Furnace. The temperature pattern i.e. gradual increase and decrease of temperature recorded by thermocouple in the classical method of preparation was utilized for preparation in MF method. (Figure 3) The temperature of

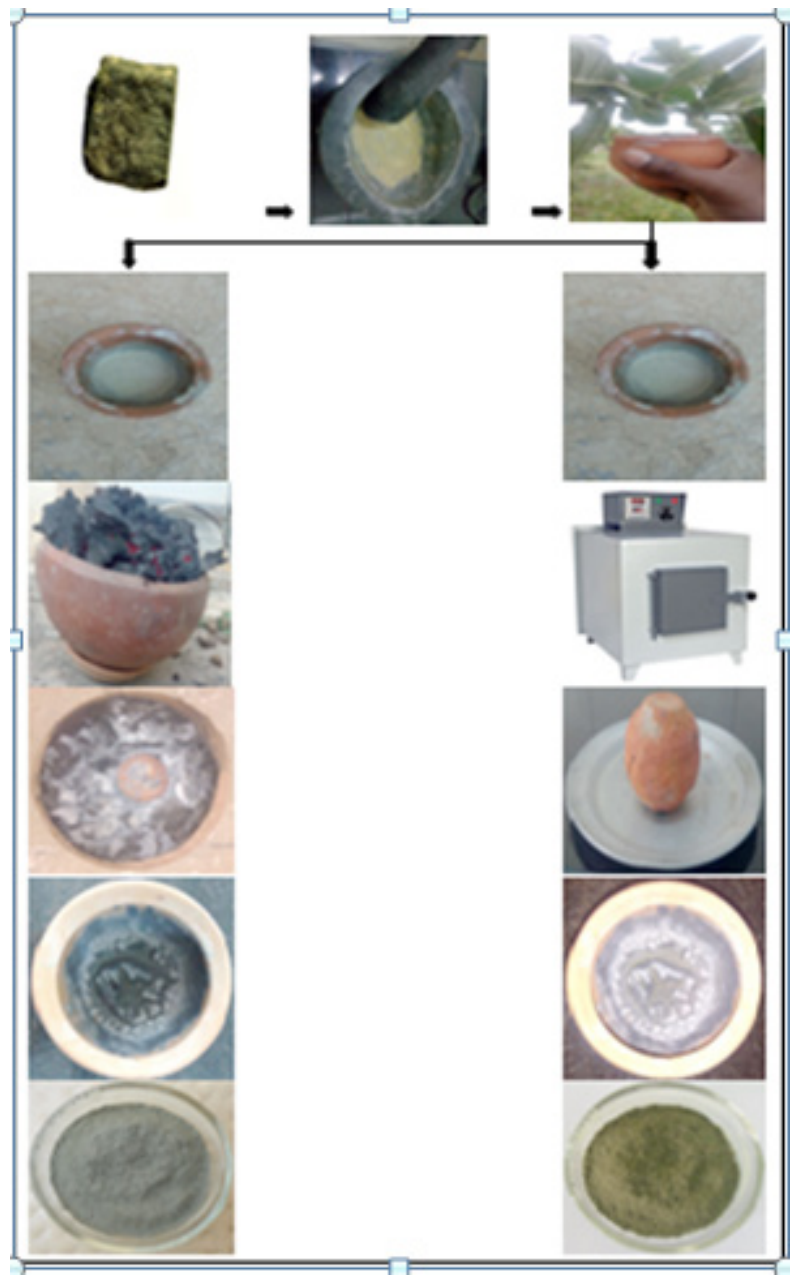

Figure 1: Schematic diagram of Kushta-e-Murdarsang formation.

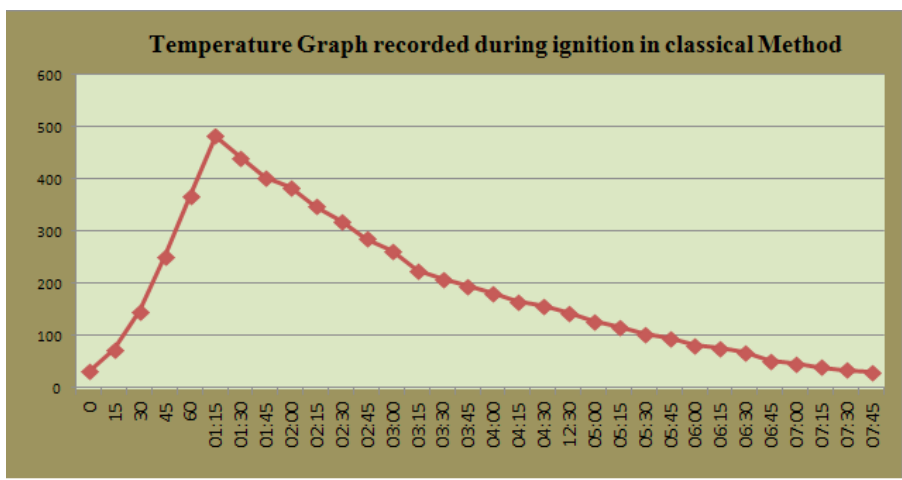

Figure 2: The mean temperature pattern of KM (classical method).

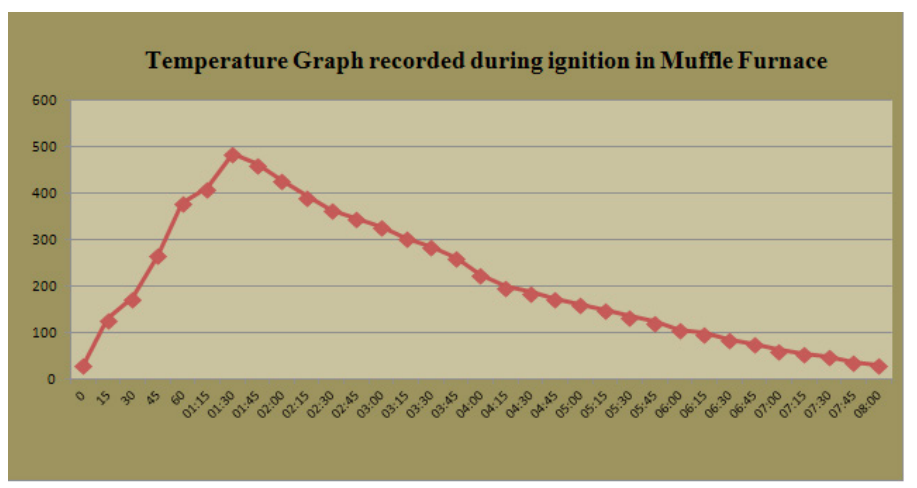

Figure 3: The mean temperature pattern of KM (Muffle Furnace method).

$483^{\circ} \mathrm{C}$ was set with gradual increase from atmospheric temperature $\left(25^{\circ} \mathrm{C}\right.$ approximate) onward and then it was again set to the same point of atmospheric temperature to set aside to cool. (Figure 1, Figure 2, Figure 3)

\section{Physico-Chemical Analysis}

Organoleptic Characters: The prepared Kushta was assessed for its Colour, ${ }^{1,7}$ Odour, ${ }^{7}$ Taste. ${ }^{7.8}$

\section{Unani specification (test)}

The Floating test, ${ }^{7,8}$ Fineness test, ${ }^{7,8}$ Loss of metallic luster ${ }^{7,8}$ was performed as per NFUM and Protocol for testing of Ayurvedic, Siddha and Unani medicine. ${ }^{7,8}$ Wall stick test, ${ }^{7}$ Smokeless test ${ }^{8-10}$ parameters are used for the analysis of proper calcination process. (Figure 4)

\section{Powder characterizations \\ Bulk density and tapped density}

Packing volume was determined by an apparatus consisting of a graduated cylinder mounted on a Jolting Volumeter (Mechanical tapping device). $10 \mathrm{gm}$ of weighed Kushta was added to the graduated cylinder. Initial volume was first noted and the sample was then tapped until no further decrease in volume of Kushta powder was observed. The bulk and tapped densities were calculated by the formula. ${ }^{11}$

$$
\text { Bulk density }=\frac{\text { Mass }}{\text { Bulk Volume }} \quad \text { Tapped Density }=\frac{\text { Mass }}{\text { Tapped Volume }}
$$

Hausner ratio: Hausner ratio was calculated with the following equation.

Hausner ratio $=\mathrm{Vo} / \mathrm{V}_{\mathrm{f}}$ 


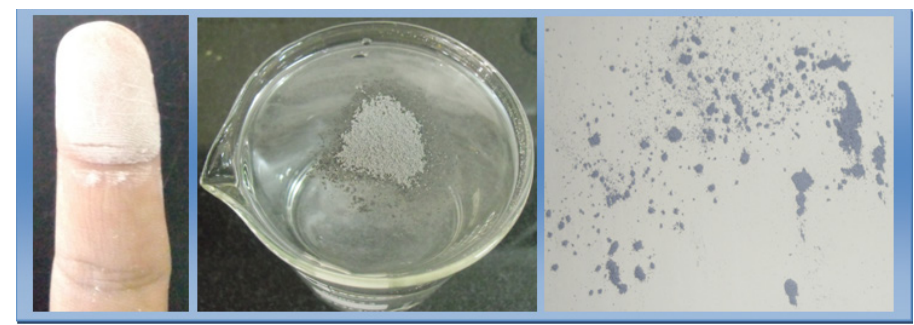

Figure 4: Unani specification tests: $L$ to $R \rightarrow$ Finger Test, Floating Test and Wall Stick Test.

Where Vo = Unsettled apparent volume, $V_{\mathrm{f}}=$ final tapped volume. ${ }^{11}$ Compressibility index (Carr's index) : It was calculated by following equation:

$$
\text { Carr's index }(\%)=\frac{\begin{array}{l}
{[\text { (unsettled apparent volume }-} \\
\text { final tapped volume }) \times 100]
\end{array}}{\text { unsettled apparent volume }}
$$

\section{Determination of angle of repose}

The angle of repose was examined by applying fixed funnel method. In this method the height of the tip of funnel was fixed two $\mathrm{cm}$ above the horizontal surface and a paper was placed below the funnel on the table. The Kushta powder was allowed to flow through the funnel freely on to the surface till the apex of the conical pile just touches the funnel tip. The diameter of the Kushta cone base was measured and the angle of repose was calculated by using this formula: ${ }^{12} \operatorname{Tan} \varnothing=2 \mathrm{~h} / \mathrm{D}, \mathrm{h}=$ height of powder (from paper to tip of funnel), $\mathrm{D}=$ mean diameter of the Kushta powder

Loss of weight on drying at $105^{\circ} \mathrm{C}(\mathrm{LoD}),{ }^{8}$ Determination of $\mathrm{pH},{ }^{8}$ Determination of Total ash, ${ }^{8}$ Determination of Acid insoluble ash, ${ }^{8}$ Determination of water soluble ash, ${ }^{8}$ was done as per protocol for testing of ASU medicine, PLIM Ghaziabad. ${ }^{8}$

\section{Particle size analysis}

(By Mesh size) The particle size investigation has been done by passing Kushta in different meshes from 80, 100, 170,200, 240, 300, 350 No \# etc, and the percentage (\%) of material passed was noted.

\section{Qualitative assessment of constituents using chemical method Inorganic}

Calcium compounds: Few drops of ammonium oxalate solution were added to the test solution. A white precipitate was formed that was sparingly soluble in $6 \mathrm{M} \mathrm{CH}_{3} \mathrm{COOH}$ but was soluble in $\mathrm{HCl} .{ }^{13}$

\section{Aluminum compounds}

20 to $25 \mathrm{mg}$ of Kushta was dissolve in $1 \mathrm{ml}$ of distilled water, and add about $0.5 \mathrm{ml}$ of $2 \mathrm{M}$ hydrochloric acid followed by $0.5 \mathrm{ml}$ of thioacetamide reagent, add $2 \mathrm{M}$ sodium hydroxide drop wise, gelatinous white ppt appears that dissolve in the excess of sodium hydroxide solution. Gradually add $2 \mathrm{M}$ ammonium chloride, the gelatinous white ppt reappears, shows the presence of Aluminium. ${ }^{13}$

\section{Arsenic compounds}

20 to $25 \mathrm{mg}$ of Kushta was dissolved in about $2 \mathrm{ml}$ of distilled water and add an equal quantity of hypophosphorous reagent. Formation of brown ppt, shows the presence of Arsenic. ${ }^{13}$

\section{Cadmium compounds}

About $25 \mathrm{mg}$ of Kushta is dissolved in about $2 \mathrm{ml}$ of distilled water and add 2 drops of dil. solution of HCL, followed by a few drop of $10 \%$ solution of sodium sulphide. A yellow ppt is formed which is insoluble in a solution of ammonium polysulphide, points out the presence of Cadmium compound. ${ }^{13}$

Mercury compounds: (a) 20 to $25 \mathrm{mg}$ of Kushta is dissolved in $1 \mathrm{ml}$ of distilled water, and add $2 \mathrm{M}$ sodium hydroxide unless solution become strongly alkaline, Dense yellow ppt. if formed, shows the presence of Mercury compounds. ${ }^{13}$ (b) 20 to $25 \mathrm{mg}$ of Kushta is dissolved in $1 \mathrm{ml}$ of distilled water, and add carefully potassium iodide solution. A red ppt is formed that dissolve in excess of reagent, it indicates the presence of Mercury compound. ${ }^{13}$

Iron compounds: $20-25 \mathrm{mg}$ of Kushta was dissolved in distilled water; $1 \mathrm{ml}$ of $5 \% \mathrm{w} / \mathrm{v}$ solution of potassium ferrocyanide was added. A dark blue colour precipitate, if formed which is insoluble in $5 \mathrm{ml}$ of $2 \mathrm{M} \mathrm{HCl}$ is confirmatory for iron compounds. ${ }^{13}$

Lead compounds: D20 to $30 \mathrm{mg}$ of Kushta is dissolved in $1 \mathrm{ml}$ of $5 \mathrm{M}$ acetic acid, and add about $5 \mathrm{ml}$ of distilled water followed by $0.2 \mathrm{ml}$ potassium iodide. A yellow ppt is formed, shows the presence of Lead compound. ${ }^{13}$

Manganese compounds: A drop of the test solution is mixed with a drop of conc. sulphuric acid, drop of $0.1 \%$ silver nitrate solution is stirred in, and then few mg of ammonium persulphate, the mixture is then gently heated. A red violet colour indicates manganese. ${ }^{13}$

Zinc compounds: 20 to $25 \mathrm{mg}$ of Kushta is dissolved in 2 to $3 \mathrm{ml}$ of distilled water, and then add $0.2 \mathrm{ml}$ of $10 \mathrm{M}$ sodium hydroxide. A white precipitate is formed which dissolves in $2 \mathrm{ml}$ of $10 \mathrm{M}$ sodium hydroxide solution. Add about $5 \mathrm{ml}$ of $2 \mathrm{M}$ ammonium chloride then $0.1 \mathrm{ml}$ of sodium sulphide solution. A flocculent, white precipitate is produce, shows the presence of Zinc. ${ }^{13}$

\section{Qualitative assessment of organic constituents using chemical method ${ }^{13,14}$}

The organic Qualitative estimation of Alkaloids, Flavonoids, Terpenoids, Tannins, Saponins, Glycosides, Steroids, Phenols, Resin, Proteins and Carbohydrates were done in both the sample KM-CM and KM-MFM.

\section{XRD Study}

$\mathrm{X}$-ray diffraction is an accurate and rapid method for recognizing the crystal structure. It is a technique through which the structural units of material and there arrangement in crystalline state is known. It is also used for chemical analysis and stress measurement, study of phase and particle size measurement as well as determination of the orientation of crystal in a polycrystalline aggregate. Also applied for differentiation among various oxides / sulphide of metals.$^{15,16}$

$\mathrm{XRD}$ works on the principle of Bragg law which can be written in the form: $\lambda=2 \mathrm{~d} \sin$. By applying Bragg's Law the distance between each set of atom planes $(\mathrm{d})$ is spirited with the help of wave length $\lambda$ of $\mathrm{x}$-ray beam and angle of diffraction $\theta .{ }^{15,16}$

\section{XRD Equipments}

$\mathrm{XRD}$ was carried out by using X-ray diffractometer at (Indian institute of Sciences) IISc, Bangalore with following specification: PAN analytical, X' pert pro, X-ray source CU k $\alpha\left(\alpha=1.5418 \mathrm{~A}^{\circ}\right)$, voltage $40 \mathrm{KV} / 30 \mathrm{MA}$, Phases were identified using the automatic search program X'Pert High Score Plus. Shimatzu corporation, Japan AY 220, digital balance and, Sieve \# no. 200, Standard test sieves Impex India was used. 


\section{Sample preparation}

In this study the powder method of $\mathrm{X}$ ray diffraction has been taken on. The $\mathrm{x}$-ray diffraction method for study of both the sample KM-CM and KM-MFM was done and for this purpose the fine $1 \mathrm{gm}$ powder of both classical (KM-CM) and muffle furnace (KM-MFM) samples were studied.

High Score Plus. X-Ray diffraction studies were conducted on both the sample. The 2-theta value and the intensity of the peak are represented on $\mathrm{X}$ and Y-axis respectively, higher peak / count value indicate higher crystallanity of the phase. Phase detection was done for both the samples. ${ }^{15,16}$

\section{RESULTS}

\section{Physicochemical Studies}

The following results were found in prepared samples of Kushta-eMurdarsang prepared by Muffle Furnace method (KM-MFM) and classical method (KM-CM) and the data is based on several observations. Organoleptic properties: Blackish in sample of $\mathrm{KM}-\mathrm{CM}$ and more whitish in sample of KM-MFM were observed. Both the samples (KM-CM and KM-MFM) were found to be odourless and tasteless. (Table 1)

Physicochemical parameters: Both the samples have passed Unani specification tests (Table 1). Data generated for Total Ash (\%), Acid Insoluble Ash (\%), Water Soluble Ash (\%), LoD (\%), pH (1\%), pH (10\%) is depicted in Table 2, Powder characterization data of $\mathrm{KM}$ is mentioned in Table 3.

\section{Qualitative estimation of constituent / element}

Organic: Alkaloids, flavonoids, terpenoids, tannins, saponins, glycosides, steroids, phenols, resin, and no any proteins and carbohydrates were found in both the sample KM-CM and KM-MFM.

Inorganic: Qualitative testing reveals that calcium, aluminum, arsenic, cadmium, iron, mercury, zinc and manganese compounds were negative and only lead compounds was found positive in both the sample of KM-MFM and KM-CM of Kushta-e-Murdarsang. (Table 4)

Table 1: Unani specification tests of Kushta-e-Murdarsang.

\begin{tabular}{ccc}
\hline Preliminary Tests & KM-CM & KM-MFM \\
\hline Floating Test & Positive & Positive \\
Fineness and smoothness Test & $\begin{array}{c}\text { Very fine and } \\
\text { smooth }\end{array}$ & Very fine and smooth \\
Loss Of Metallic Luster & Positive & Positive \\
Wall Stick Test & Positive & Positive \\
Smokeless Test & Positive & Positive \\
\hline
\end{tabular}

Note: KM-CM = Kushta-e-Murdarsang prepared by classical method; KM-MFM = Kushta-e-Murdarsang prepared by Muffle Furnace method

Table 2: Physicochemical parameters.

\begin{tabular}{ccc}
\hline Physicochemical Parameters & KM-CM & KM-MFM \\
\hline Total Ash (\%) & $99.991 \pm 0.000$ & $99.988 \pm 0.001$ \\
Acid Insoluble Ash (\%) & $99.350 \pm 0.045$ & $99.661 \pm 0.041$ \\
Water Soluble Ash (\%) & $0.011 \pm 0.001$ & $0.074 \pm 0.006$ \\
Loss of weight on drying (\%) & $0.017 \pm 0.002$ & $0.027 \pm 0.007$ \\
pH (1 \%) & $8.893 \pm 0.040$ & $9.353 \pm 0.017$ \\
pH (10 \%) & $9.363 \pm 0.029$ & $9.553 \pm 0.017$ \\
\hline
\end{tabular}

Mean \pm SEM (Standard error of mean)

\begin{tabular}{ccc} 
Table 3: Powder characterization study. \\
\hline Powder characterization & KM-CM & KM-MFM \\
\hline Bulk Density $(\mathrm{gm} / \mathrm{ml})$ & $0.219 \pm 0.002$ & $0.2246 \pm 0.003$ \\
Tapped Density $(\mathrm{gm} / \mathrm{ml})$ & $0.3921 \pm 0.00$ & $0.3522 \pm 0.018$ \\
Hausner's ratio & $1.7908 \pm 0.017$ & $1.508 \pm 0.015$ \\
Compressibility index $(\%)$ & $44.1502 \pm 0.536$ & $34.332 \pm 1.185$ \\
Angle of repose $(\theta)$ & $48.51 \pm 0.266$ & $43.29 \pm 1.063$ \\
\hline
\end{tabular}

Mean \pm SEM (Standard error of mean)

Table 4: Qualitative estimation (Inorganic).

\begin{tabular}{|c|c|c|c|}
\hline S. No & $\begin{array}{c}\text { Name of compound/ } \\
\text { element }\end{array}$ & Classical Method & Muffle Furnace \\
\hline 1 & Calcium compounds & -ve & -ve \\
\hline 2 & Aluminum compounds & -ve & -ve \\
\hline 3 & Arsenic compounds & -ve & -ve \\
\hline 4 & Cadmium compounds & -ve & -ve \\
\hline 5 & Mercury compounds & -ve & -ve \\
\hline 6 & Iron compounds & -ve & -ve \\
\hline 7 & Lead compounds & + ve & +ve \\
\hline 8 & Manganese compounds & -ve & -ve \\
\hline 9 & Zinc compounds & -ve & -ve \\
\hline
\end{tabular}

Table 5: Heavy Metals test in Kushta-e- Murdarsang prepared by classical and Muffle Furness (MF) method.

\begin{tabular}{ccccc}
\hline S.N & Parameters & $\begin{array}{c}\text { KM-MF } \\
\text { method }\end{array}$ & $\begin{array}{c}\text { KM-Classical } \\
\text { method }\end{array}$ & Protocol \\
\hline 1. & Lead as $\mathrm{Pb}$ & $55.0 \%$ & $51.4 \%$ & AA-7 \\
2. & Cadmium as Cd & $0.65 \mathrm{ppm}$ & $0.65 \mathrm{ppm}$ & ICPMS \\
3. & Mercury as Hg & $54.17 \mathrm{ppm}$ & $68.08 \mathrm{ppm}$ & ICPMS \\
4. & Arsenic as As & $21.27 \mathrm{ppm}$ & $0.11 \%$ & ICPMS \\
\hline
\end{tabular}

Heavy metal: Both the sample KM-CM and KM-MFM showed presence of heavy metals Lead ( $\mathrm{Pb})$, Cadmium (Cd), Mercury (Hg), Arsenic (As) above permissible limit, except As in KM-CM was under permissible limit. Lead in both the sample was in higher limit. All the values are depicted in Table 5.

XRD Study: Both the sample KM-CM and KM-MFM showed presence of Lead phase in XRD findings, KM-MFM revealed presence of Litharge syn- $\mathrm{PbO}$ phase, and sample of $\mathrm{KM}-\mathrm{CM}$ revealed presence of Lead syn- $\mathrm{Pb}$, Galena syn- $\mathrm{Pb} \mathrm{S}$ and Litharge syn- $\mathrm{Pb} \mathrm{O}$ phase. (Table 5), (Figures 5-7).

\section{DISCUSSION}

Kushta is one of the important dosage forms of Unani Medicine like Ayurvedic medicine. In ancient days, the Unani physicians opposed use of Kushta dosage form because of an apprehension that the imperfect Kushta prepared by inexperienced people could be disastrous and even life threatening. They believed that the unjust usage of Kushta instead of doing good could be more dangerous by invoking irreversible damages. Historic past reveals the usage of metals in Bhasma or Kushta form was common in India for centuries. ${ }^{1}$ Kushta-e-Murdarsang is important drug in Unani Medicine. The study reveals safety aspect of Kushta-e-Murdarsang in respect of quantity of heavy metal. Blackish white colour was seen in 


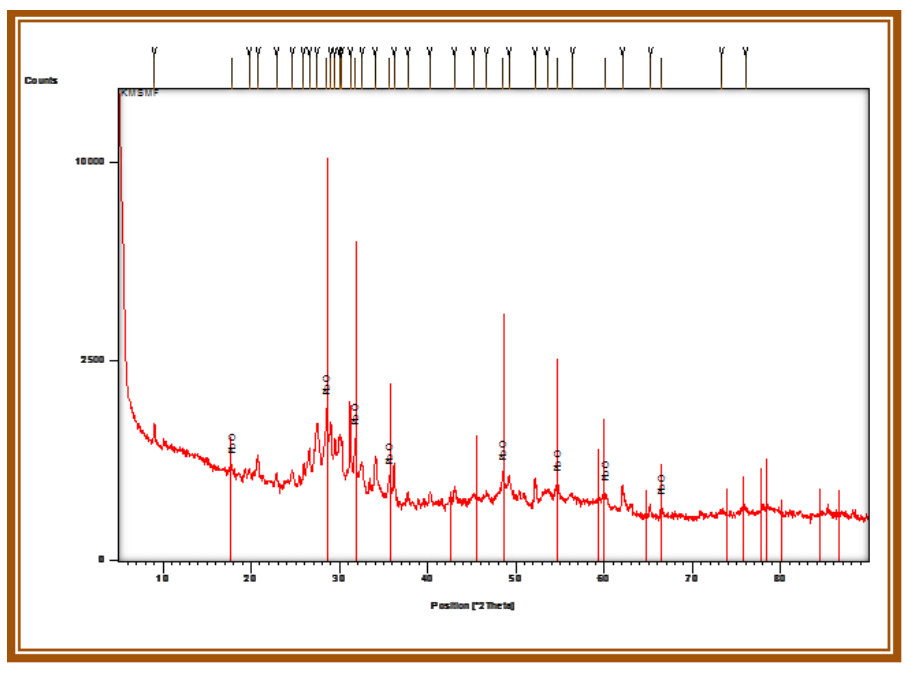

Figure 5: XRD findings of KMS-MF revealed presence of Litharge syn- $\mathrm{PbO}$ phase.

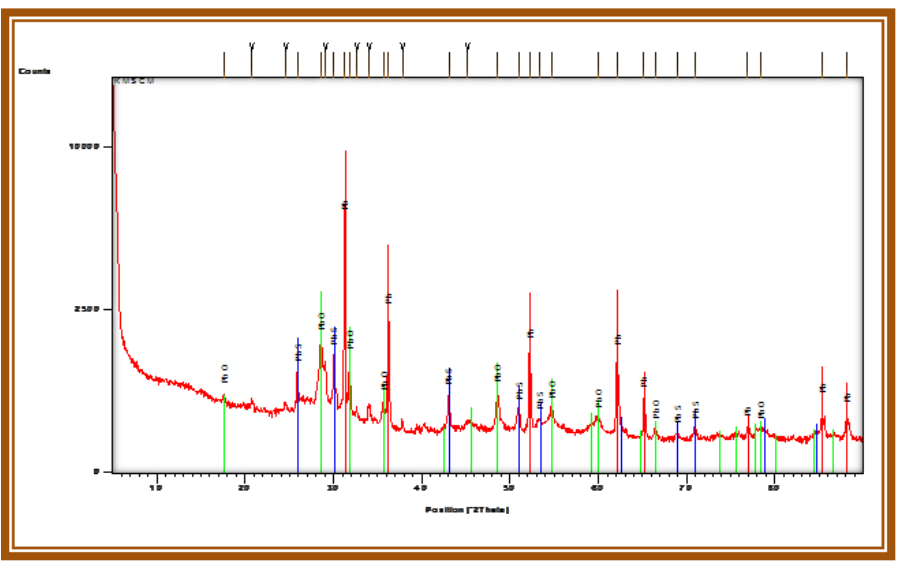

Figure 6: XRD findings of KMS-CM revealed presence of Lead syn- $\mathrm{Pb}$, Galena syn- $\mathrm{Pb} \mathrm{S}$ and Litharge syn- $\mathrm{Pb} \mathrm{O}$ phase.

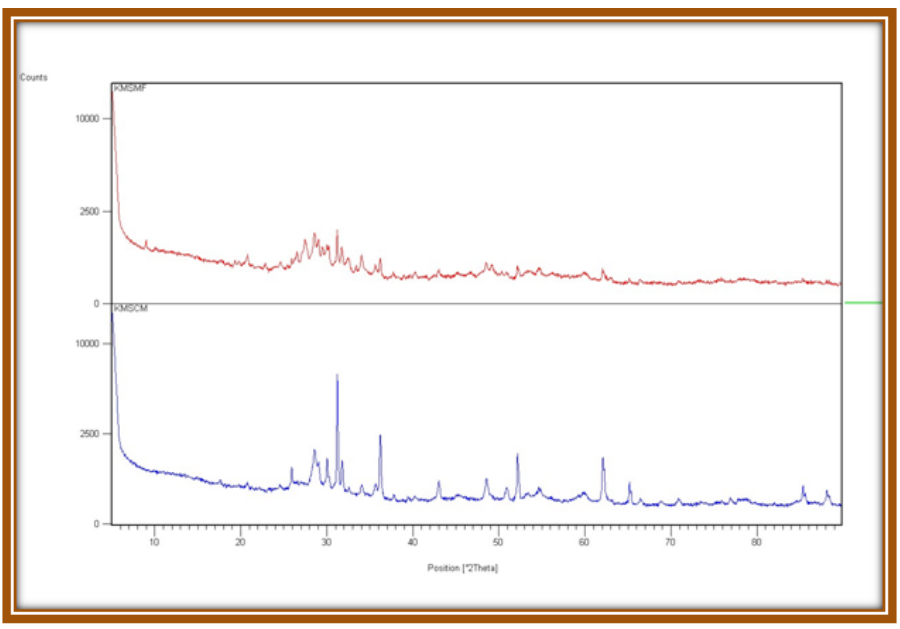

Figure 7: Combine XRD of Sample KM-CM and KM-MFM. sample of KM-CM and more whitish colour in sample of KM-MFM. This indicates the Muffle Furnace method is near to Kamil property mentioned in Unani texts. ${ }^{7}$ Both the sample of KM passes Unani classical test for specification such as floating, fineness smoothness, wall stick and smokeless test, loss of metallic luster was also noted, these tests are indicative of classical quality parameters.

Total and acid insoluble Ash in both the sample were above 99\% which indicates presence of mostly inorganic constituents, $\mathrm{pH}$ of both the samples were slightly basic. In powder characterization test Hausner's ratio and Compressibility index (\%) displays poor flow property in both the group KM-MFM and KM-CM which may be due to amorphous nature of Kushta due to incineration. KM-CM. showed poor flowability slightly more than KM-MFM.

Presence of Lead phase is confirmed in XRD findings of both the sample, KM-MFM revealed presence of Litharge syn-PbO phase, and KM-CM revealed presence of Lead syn- $\mathrm{Pb}$, Galena syn- $\mathrm{PbS}$ and also Litharge syn- $\mathrm{PbO}$ phase (Table 5) Presence of Lead was also confirmed by inorganic qualitative estimation. (Table 4) There are some limitations of XRD that it does not facilitate detection of trace element and amorphous solid. ${ }^{15,16}$

Study of composition revealed that Murdarsang is formed with lead., ${ }^{5,17}$ Murdarsang is basically termed as mono-oxide of lead. ${ }^{6}$ Murdarsang is commonly used externally. According to the Unani physicians Murdarsang has sammiyat (toxicity) so it should be used internally with caution. ${ }^{17,20}$ according to Najmul Ghani (1859-1899) Murdarsang is not commonly used internally due to its sammiyat (toxicity) so it is generally used in skin diseases formulations that are usually applied externally / topically., ${ }^{5,21}$

Both the sample KM-CM and KM-MFM display near about similar characteristics except colour was more whitish in MFM, and it also showed only phase of $\mathrm{PbO}$ which might be due to proper oxidation process during incineration. Thermal decomposition of lead causes its conversion in $\mathrm{PbO}$. At high temperature galena (lead (II) sulfide) a lead ore is converted to the oxide..$^{22} \mathrm{KM}$ prepared by muffle Furnace can also be a better choice by simulating classical heat pattern owing to the results obtain. When compared in respect of toxicity it may be more toxic when compared to classical method which contain Lead sulphide Pbs with Pbo, as Lead sulfide is so insoluble that it is almost nontoxic. ${ }^{23}$ Data obtain for both the method is a preliminary and needs further investigation in respect of toxicity and proper method of preparation and its efficacy claimed also needs exploration. Both the samples displays heavy metal above permissible limit except As in KM-CM was under limit. Pure Lead oxide may be fatal if taken internally. It can affect central nervous system, kidneys, blood, and reproductive system. It cans bio-accumulate in mammals. ${ }^{24}$ The primary cause of toxicity of lead is its predilection for interfering with the proper functioning of enzymes. ${ }^{25}$

This study validates claim by Unani physician regarding toxicity of this preparation and cautioned use. As results of the study indicates that this formulation should be avoided for the systemic use. The benefit to risk assessment should be made for using it internally or even locally particularly in case of eroded skin. Further sophisticated and toxicological studies are need for additional comment on its toxicity. Investigation is also needed to study the reduced toxicity if any after Mudabbar or incineration or killing (Kushta) process. In present work physicochemical data for KM for both classical and contemporary process was established which can help in further study and elemental phase / heavy metal were assessed in the formulation for toxicity concern.

\section{CONCLUSION}

It can be concluded that the both the sample prepared by classical as well as muffle Furness method contains heavy metal above permissible limit 
and KM-CM contain reduced quantity of heavy metal in respect of MF method. KM-MFM can be better option in respect of Unani concept of Kamil (complete) Kushta.

\section{ACKNOWLEDGEMENT}

The authors would like to express their thanks to Director, National Institute of Unani Medicine (NIUM) Bangalore, for his motivation to work. We also express thanks to Prof. Rajeev Ranjan, Department of Materials Engineering, Indian Institute of Science, Bangalore and his XRD team for better cooperation and well support for the same.

\section{CONFLICT OF INTEREST}

The authors declare no conflict of interest.

\section{ABBREVIATIONS}

XRD: X-ray diffraction; ICP-MS: inductively coupled plasma mass spectrometry; AAS: Atomic absorption spectroscopy; KM-CM: Kushta-eMurdarsang classical method; KM-MFM: Kushta-e-Murdarsang Muffle Furnace method; USM: Unani System of Medicine; NIUM: National Institute of Unani Medicine; IISc: Indian Institute of sciences; SEM: Standard error of mean.

\section{REFERENCES}

1. Kabiruddin HM, Al-Taklees K. New Delhi: Central council for Research in Una ni Medicine [reprint]. p. 20.

2. Sharma R, Prajapati PK. Nanotechnology in medicine: leads from Ayurveda. J Pharm Bioallied Sci. 2016;8(1):80-1. doi: 10.4103/0975-7406.171730, PMID 26957877.

3. Prajapati PK, Sarkar PK, Nayak SV, Joshi RD, Ravishankar B. Safety and toxicity profile of some metallic preparations of Ayurveda. Anc Sci Life. 2006;25(34):57-63. PMID 22557208

4. Andrew M, Shastra R -The Hidden Art of Medical Alchemy. Singing dragon. $1^{\text {st }}$ ed. London, UK: Jessica Kingsley Publishers; 2014. p. 508.

5. Najmulghani. Khazain al-Advia New Delhi: idara kitab Al-Shifa [reprint]; 1235-1236.

6. Anonymous. National formulary of Una ni medicine. Part-Vi. New Delhi: Ministry of H \& FW; 2011:154

7. Anonymous. National formulary of Una ni medicine. Part 1. First Reprint New Delhi Cent Counc Res Unani Med. 2006;66.

8. Anonymous. Protocol for testing of Ayurvedic, Siddha, and Una ni medicine. Govt. of India dept. of AYUSH ministry of health and family welfare, pharmacopeial laboratory for Indian medicine Ghaziabad; 2007.

9. Firozuddin M. Madanul Akseer. New Delhi: Central council for Research in Una ni Medicine. 2007;22:26, 40, 43, 47-171.

10. Hafeez HA. Sanatul Taklees. New Delhi: Central council for Research in Unani Medicine; 2005.74-7

11. Remington. The science of practice of Pharmacy. 21st ed vol. I. New Delhi: Wolters kluwer; 2011. p. 711-4.

12. Ali W, Shaikh $H$, Ansari A, Khanam S. Standardization of Unani Antidiabetic Tablet - Qurse Tabasheer. Pharmacognosy Res. 2016;8(2):147-52. doi: 10.4103/0974-8490.175611. PMID 27034607.

13. Anonymous. Physicochemical Standards of Unani Formulations. Part IV. 1st ed. New Delhi: Central Council of Research in Unani Medicine. 2006;325(144):150-57.

14. Anonymous. Standardisation of single drugs of Una ni medicine. Part I. New Delhi: Central council for Research in Una ni Medicine; Year not mentioned: 162-5, 202-4.

15. Cullity BD. Elements of x-ray diffraction. In: the United States of America, Addison - Wesley publishing company. Inc. 1956; 1956.

16. Sharma BK Sharma M, editor. Instrumental methods of chemical analysis. 21st ed. Meerut: Goel Publisher; 2002.

17. Kabeeruddin M, Al-Mufradat M New Delhi: Faisal Brother Publisher; 2000:384.

18. Hakim HMA. Bustan al-Mufradat Jadid New Delhi: idara kitab Al-Shifa. Vol. 311; 2002

19. Rasa Shastra AM. The hidden art of medical alchemy. $1^{\text {st }}$ ed. Singing dragon. London, UK: Jessica Kingsley Publishers; 2014. p. 508

20. Ali S. Unani Advia Mufrada. $5^{\text {th }}$ ed. New Delhi: Traqqi Urdu Beuro; 1989:316.

21. Majusi ABA, Al-Sana K'h. $1^{\text {st }}$ ed. Vol. II, New Delhi: Idara Kitab Al-Shifa; 2010:169.

22. Abdel-Rehim AM. Thermal and XRD analysis of Egyptian galena. J Therm Anal Calorim. 2006;86(2):393-401. doi: 10.1007/s10973-005-6785-6.

23. Lead Sulfide. https://www. espimetals. com /index .php/msds /208-Lead $\% 20$ Sulfide. Revised / Reviewed: August 2017. Accessed on 27 June 2021.

24. Lead(II) oxide. International Occupational Safety and Health Information Centre. Archived from the original on 2011-12-15. [retrieved 2009/6/6]. [accessed on 19/7/2021].

25. Rudolph AM, Rudolph CD, Hostetter MK; et al. Lead. Rudolph's pediatrics. $21^{\text {st }}$ ed. McGraw-Hill Professional. 2003:369.

Article History: Received: 06-06-2021; Revised: 02-07-2021; Accepted: 29-07-2021.

Cite this article: Ali MA, Hamiduddin, Zaigham M, Nafees S, Ikram M, Jahangeer G. Comparative Physicochemical Analysis of Kushta-E-Murdarsang Prepared by Classical and Muffle Furness Method. J Young Pharm. 2021;13(3):205-10. 